\title{
ASSESSMENT OF ENVIRONMENTAL IMPACT OF SOLID WASTE DUMPSITES USING REMOTE SENSING
}

\author{
I. T. Ekeu-wei ${ }^{1,}{ }^{*}$, K. I. Azuma ${ }^{2}$ and F. B. B. Ogunmuyiwa ${ }^{3}$ \\ 1. LANCASTER ENVIRONMENT CENTRE, UNIVERSITY OF LANCASTER, UNITED KINGDOM \\ 2, Dept. of Animal and EnVIRonmental Biology, University of BEnin, BEnin, Edo State, NigERIA

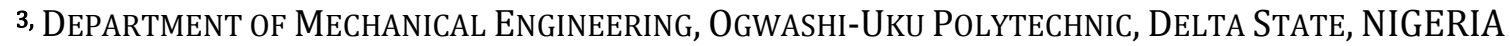 \\ Email addresses:1i.ekeu-wei@lancaster.ac.uk,2kate_azuma@yahoo.com,3buloere@gmail.com
}

\begin{abstract}
This study presents a remote sensing approach of using freely available Landsat 8 satellite Indicators (Land Surface Temperature (LST), Soil Adjusted Vegetation Index (SAVI)) and Shuttle Radar Topography Mission (SRTM) Digital Elevation Model (DEM) geospatial data to assess the impact of dumpsites on the environment in Benin City, Nigeria. The finding reveals that the average derived LST at the dumpsites were higher than the immediate surrounding, and the average SAVI values were lower than the immediate surrounding. The high values of LST at the dumpsites depict the effect of gases released because of decomposition activities, while low values of SAVI indicate vegetation response to soil and ground water contamination due to leachate infiltration. The average elevation within the dumpsite area derived from SRTM DEM was also applied as a proxy to estimate disposed waste quantity, and related closely with LST that depict biodegradation activities. The result presented here shows that bacterial and fungal counts correlate strongly with the LST and SAVI values at each of the dumpsites $R^{2}$ : LST vs Bacteria Count $=0.982$, LST vs Fungi Count $=0.951 ;$ SAVI vs Bacteria Count $=0.745$, SAVI vs Fungi Count $=0.664$, thereby suggesting remote sensing can be applied to aid longterm dumpsite monitoring and management.
\end{abstract}

Keywords: Municipal solid waste, Land Surface Temperature (LST), Soil Adjusted Vegetation Index (SAVI), and Remote sensing

\section{INTRODUCTION}

Waste management is a major challenge for cities in developing countries, owing to the increasing stream of waste generated, driven by population growth, industrialization and urbanization [1,2], as well as the financial burden of waste management and lack of technical capacity [3, 4]. Municipal Solid Waste (MSW) emanate from industrial and residential activities and generally consist of food, plastic, metal, paper, textile, glass, etc. $[5,6]$.

According to the World Bank, urban population of low and middle-income countries is expected to double from 2 to 4 billion between 2000 and 2030 [7], and the UNDP further predicted that nearly all of the expected growth of the world population (until 2050) will be concentrated in the urban areas of the less developed regions [8]. Benin city, is one of the prestigious and fastest growing cities in Nigeria, with an estimated urbanization rate of 5.5 percent and an annual population growth is 2.7 percent $[9,10]$.
Benin city like most urban areas in developing regions faces the challenge of municipal solid waste management, and Ogu [11] established that only sixtysix (66) percent of waste generated in the city is regularly collected for disposal, leaving thirty-four (34) percent of generated waste where it was generated. Several studies [11-14] have also lamented the poor waste management practices in Benin City, dominated mostly by open waste disposal that consequently cause a public nuisance, generate foul odour, and expose the populace and environment to pollution and potential health impacts. Considering the growing population and urban sprawl in the city [15], this negative trend is expected to continue if left unchecked.

Waste management policies in Nigeria are formulated at the Federal and State government levels, while implementation is executed at the Local level [16]. In Benin City, the Edo State Environmental and Waste Management Board and the Local Government Authority are responsible for waste collection points 
establishment, waste collection and disposal in dumpsites [17]. Municipal solid waste management in the city typically entails waste collection, transportation, and disposal or recycling [12], which if executed haphazardly result in the exposure people and the environment (air, water and land) to pollution [18].

Geospatial Technology (GT) has been widely applied in recent years in waste management, including to understand the extent of exposure of people and the environment to waste pollution and/or contamination due to poor waste management practices. The recent review by Hannan et al., [19] disclosed some of the areas of GT application in waste management to include (i) Geographic Information System (GIS): Site selection; planning; management; Waste collection bin distribution optimization; (ii) Global Positioning System (GPS): Route and collection optimization; vehicle tracking; planning; scheduling; billing; Remote Sensing (RS): Site selection; environmental impact assessment; features monitoring; and (iv) Sensor Imaging (SI): Sorting; optimization; moisture; energy and odour measurement; scheduling waste sorting; route and collection optimization; and monitoring.

In Nigeria, GIS and RS technology have mostly been explored for dumpsite suitability analysis, waste transportation network optimization, distribution of solid waste collection facilities, and waste management system monitoring [20-23], while environment impact monitoring have predominantly been based on tedious in-situ biological and chemical approaches, that provide accurate measures of environmental contamination [24, 25], but lack spatial context.

This study presents an approach to assess the environmental impact of municipal solid waste disposal sites (legal and illegal), through the application of freely available satellite and geospatial datasets. The specific objective of this study to:

1. Assess the environmental impact of solid waste dumpsites, using satellite-derived indices.

2. Compare the satellite approach from this study with the results derived from bio-physical approaches previously applied in the same study area.

3. Identify the factors that contribute to increased dumpsite impact on the environment.

\section{MATERIALS AND METHOD}

\subsection{Study Area: Benin City}

Edo state (Figure 1) is in the Niger Delta south region of Nigeria, bordered by Kogi state (North), Ondo and Delta states (West-South) and (East-South) respectively. The state encompasses eighteen (18) Local Government Areas (LGA), and Benin-City is the economic centre and capital, is made up of three LGAs (Oredo, Egor, and Ikpoba-Okha). Edo state covers a $17,802 \mathrm{~km}^{2}$ land area with a population of 3,233,366 people [26] growing at the rate of $2.7 \%$ [27] and a continuously increasing urban area [28]. The waste generation per capital of Benin city is estimated at $0.5 \mathrm{~kg}$ per person per day [18], equating a total of $1,616,683 \mathrm{~kg}$ per day in total.

\subsection{Benin city trend: Urbanization, Population growth and Municipal Solid Waste}

Population and urbanization are the two main drivers of production and consumption, that consequently result in waste generation [17]. Population growth results in increased demand for goods and services and consequently waste generation. Urbanization, on the other hand, highlights the need for proper land use management due to growing infrastructural demand and development, thereby resulting in reduced tolerance for improper waste disposal in residential areas $[5,18,29]$. The population and land area plot for Edo state (Figure 2) reveals the urbanization scale of LGAs in Edo state, and the LGAs that constitute Benin city (Oredo, Egor, and Ikpoba-Okha) represented by dark circular makers can be identified as the only LGAs where population grossly exceeds available land. The high population density in Benin City epitomizes the inevitable municipal solid waste and land management challenges associated with population growth and this has been similarly highlighted in other studies [11 - 15, $17,18,25,28]$.

\subsection{Data}

The data used in this study were acquired primarily from open sources, i.e. remote sensing, open geospatial data portals and the Edo state open-data platform. Data of coordinates and status (legal or illegal) of dumpsites, local government area land size and population were obtained from the Edo State Open Data portal, though the weblink: www.data.edostate.gov.ng [26]. Three (3) legal and one (1) illegal dumpsite (s) in Benin City were explored in this study and are the focus of the analysis and results presented subsequently; they include Ikhueniro, Ugbowo, Oluku and Owoseni Junction. These four sites are considered due to their variation in status, size and the surrounding environment, and because of availability of previous literature $[14,25]$ at these locations to enable the comparability of our approach with other studies that were based on bio-physical 
methods. Table 1 details the properties of the dumpsites explored and Figure 3 shows the four sites in relation to their surrounding environments (vegetation, buildings and roads).

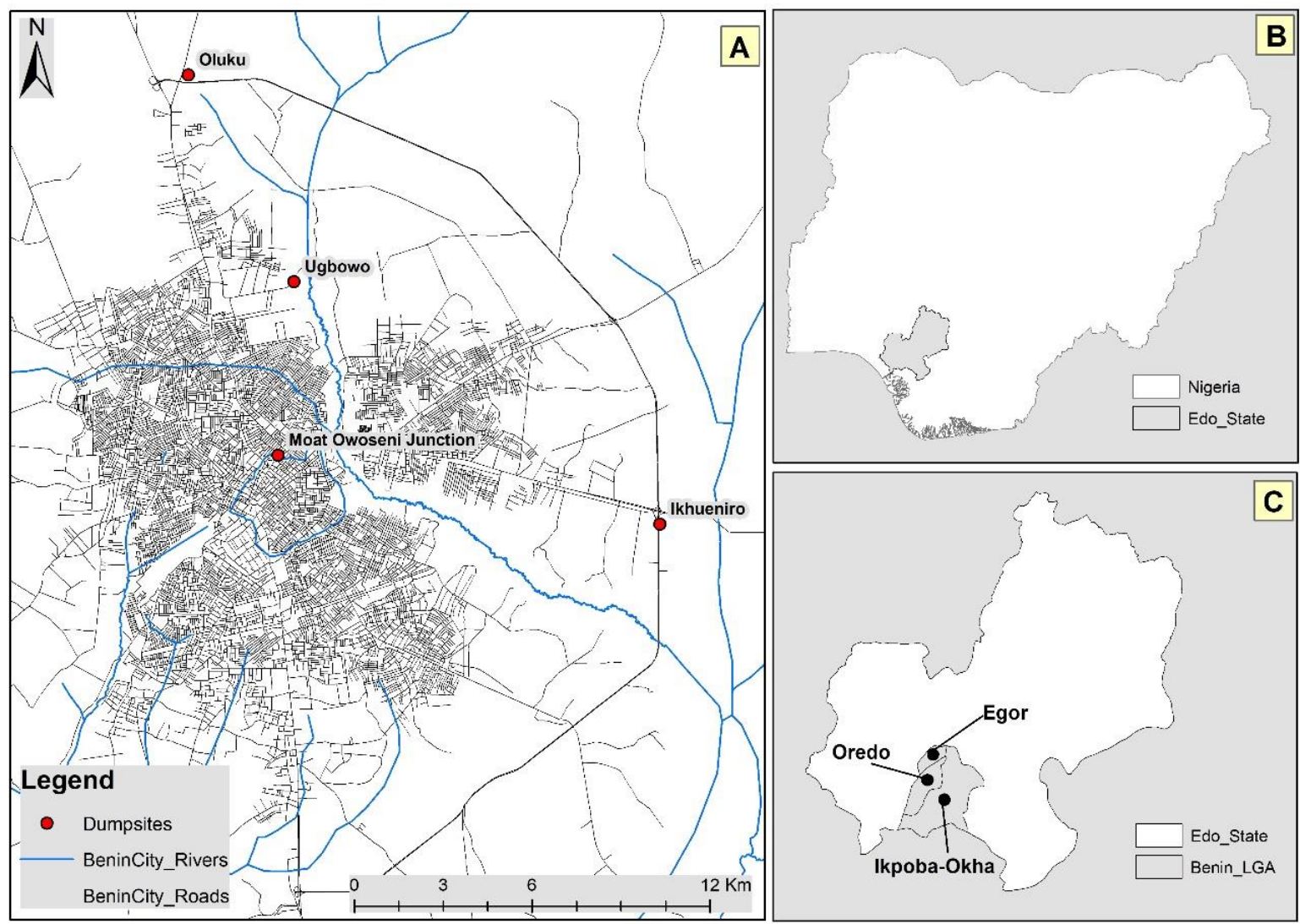

Figure 1: Map of study area: (A) Map of distribution of dumpsites, roads and river in Benin City; (B) Map showing Edo state within Nigeria; and (C) Map showing Edo state and LGAs that constitute Benin City.

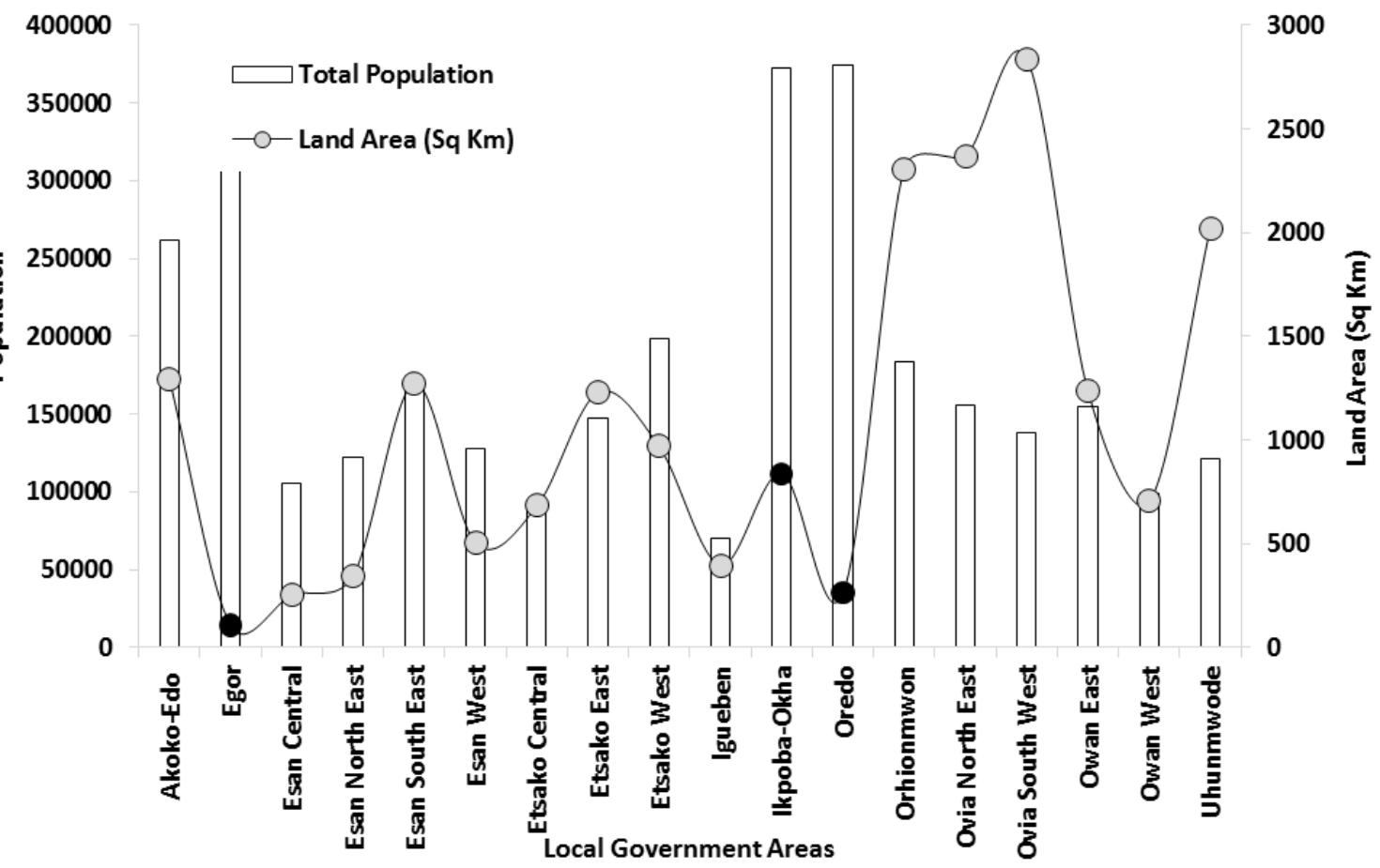

Figure 2: Plot of land size in relation to residing population of Edo state LGAs 
Table 1: Properties of explored dumpsites

\begin{tabular}{|c|c|c|c|c|c|}
\hline $\mathrm{S} / \mathrm{N}$ & Dumpsites & Status & Latitude & Longitude & Area $\left(\mathrm{m}^{2}\right)$ \\
\hline 1 & Ikhueniro & Legal & $6^{\circ} 19^{\prime} 36.92^{\prime \prime} \mathrm{N}$ & $5^{\circ} 44^{\prime} 47.31 " \mathrm{E}$ & 47.6 \\
\hline 2 & Ugbowo & Legal & $6^{\circ} 24^{\prime} 0.28^{\prime \prime} \mathrm{N}$ & $5^{\circ} 38^{\prime} 4.41 " \mathrm{E}$ & 14.2 \\
\hline 3 & Oluku & Legal & $6^{\circ} 27^{\prime} 46.43^{\prime \prime} \mathrm{N}$ & $5^{\circ} 36^{\prime} 6.77 " \mathrm{E}$ & 29.2 \\
\hline 4 & Moat Owoseni Junction & Illegal & $6^{\circ} 20^{\prime} 49.96 " \mathrm{~N}$ & $5^{\circ} 37^{\prime} 48.27^{\prime \prime} \mathrm{E}$ & 0.0018 \\
\hline
\end{tabular}
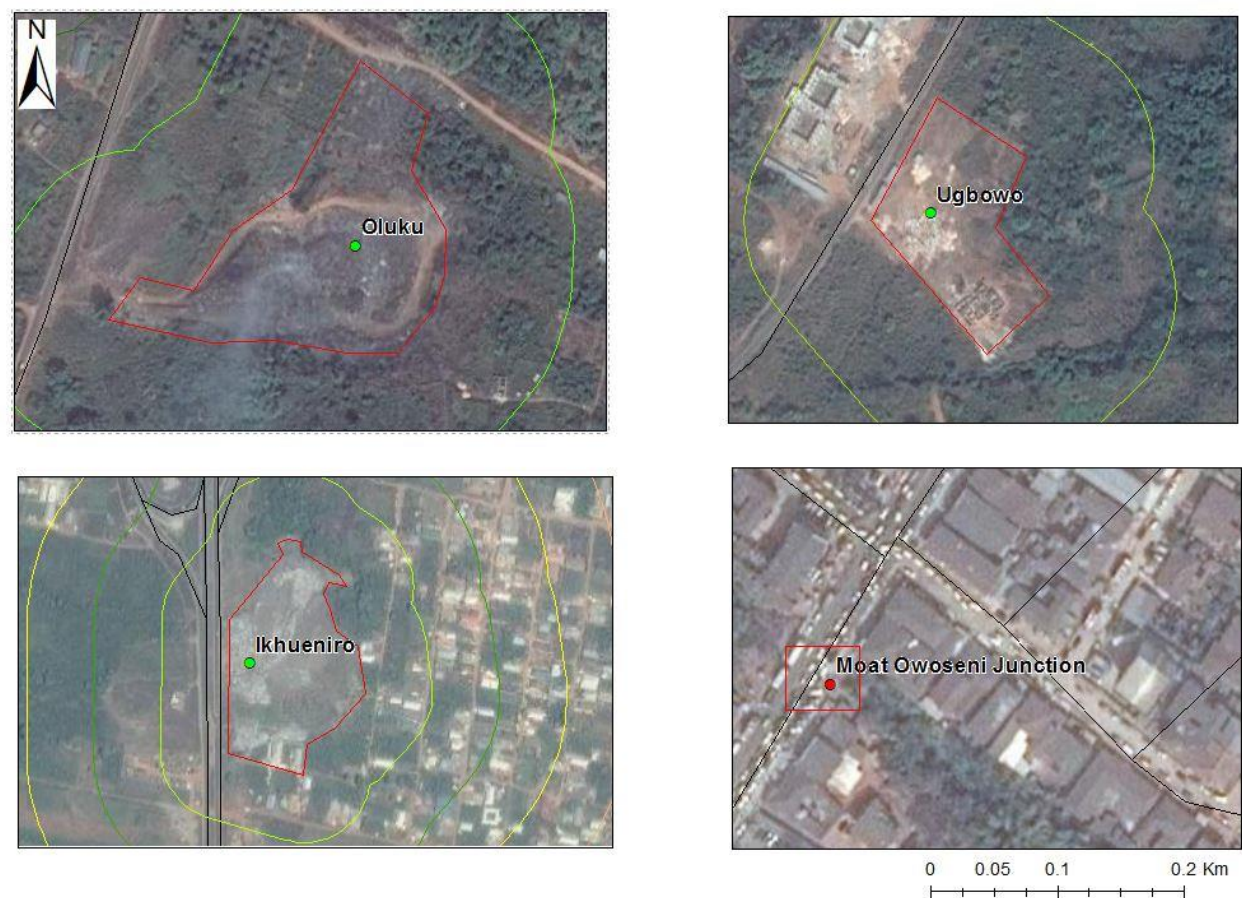

Figure 3 Legal and illegal dumpsites locations and environs extracted from Google Earth

Table 2: Landsat-8 and SRTM data properties

\begin{tabular}{cccccc}
\hline Satellite & Path/Row & Date & No. of Bands & Spatial resolution $(\mathrm{m})$ & Temporal Resolution \\
\hline Landsat 8 & $189 / 56$ & 15-Mar-2016 & 11 & 30 & 16 days \\
SRTM & $189 / 56$ & 11-Feb-2000 & 1 & 30 & 1 time mission \\
\hline
\end{tabular}

Administrative data of state and local government boundaries were downloaded from the Diva-GIS database (http://www.diva-gis.org/) [32], while road network data was acquired from the Trimble Data Marketplace (https://market.trimbledata.com).

Remote sensing Landsat-8 [30] and Shuttle Radar Topography Mission (SRTM) digital elevation model [31] were downloaded from the United States Geological Survey (USGS) explore database: http://earthexplorer.usgs.gov/. Landsat-8 Operational Land Imager (OLI) image (Row/Path: 189/56) of March 15, 2016, and SRTM acquired February 11, 2000, were used in this study (Table 2). All image processing and spatial analysis including Land Surface Temperature (LST), Soil Adjusted Vegetation Indices (SAVI), Zonal statistics, overlay and visualization were undertaken using ArcMap 10.3. The properties of Landsat 8 and SRTM datasets are presented in Table 2.

\subsection{Atmospheric correction, Land Surface Temperature (LST) and Soil Adjusted Vegetation Index (SAVI) \\ 2.4.1. Atmospheric Correction}

In this study, absolute atmospheric correction model [33] was executed within ArcMap 10.3 to correct the effect of multiple atmospheric conditions (pressure, air temperature, humidity, aerosols, solar zenith angle, etc.) on the multi-spectral Landsat-8 image. Land Surface Temperature (LST) and the Soil Adjusted Vegetation Index (SAVI) are then derived from the corrected images. The information required for atmospheric correction, i.e. sensor information (sensor type, Band details), atmospheric conditions, calibration information and correction parameters (solar angle and azimuth), were embedded in the metadata file of the acquired Landsat image [34].

The workflow for this study (Figure 4) is adapted from Shaker et al., [35]. 


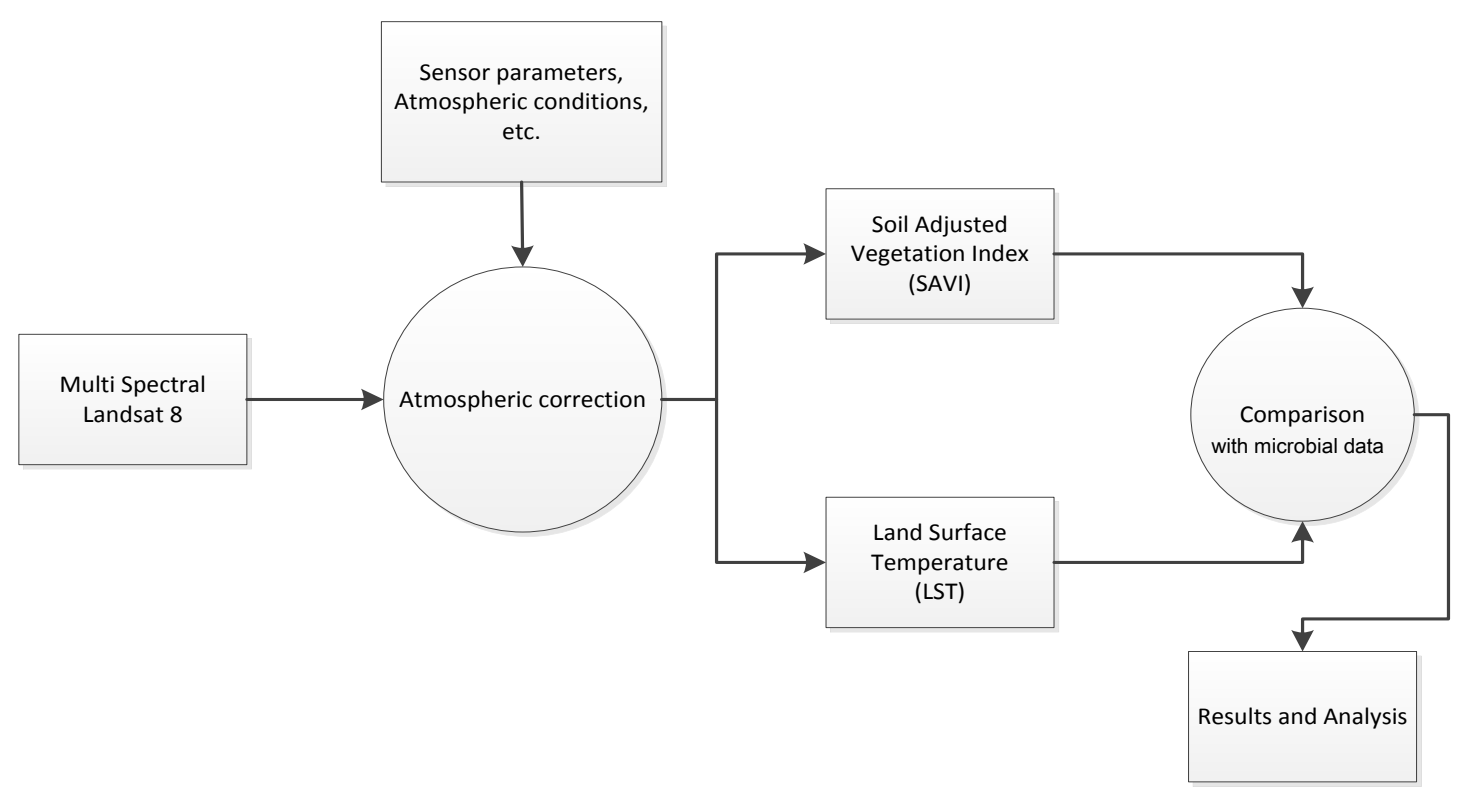

Figure 4: Atmospheric correction, LST and SAVI workflow

The formulas for atmospheric correction of Landsat-8 imager from Digital Number (DN) to Top of Atmosphere (TOA) reflectance using reflectance rescaling coefficients from Landsat- 8 metadata file are presented in equations 1 and 2 .

$$
\rho \lambda^{\prime}=M \rho Q c a l+A \rho
$$

where: $\rho \lambda^{\prime}=$ TOA is the planetary reflectance without correction for the solar angle., $\mathrm{M} \rho=$ Band-specific multiplicative rescaling factor from the metadata, A $\rho=$ Band-specific additive rescaling factor from the metadata, Qcal = Quantized and calibrated standard product pixel values (DN). TOA reflectance corrected for the sun angle is:

$$
\rho \lambda=\frac{\rho \lambda^{\prime}}{\cos \left(\theta_{S Z}\right)}=\frac{\rho \lambda^{\prime}}{\cos \left(\theta_{S E}\right)}
$$

where: $\rho \lambda=$ TOA planetary reflectance, $\theta_{S Z}=$ Local sun elevation angle. The scene center sun elevation angle in degrees is provided in the metadata (Sun Elevation), $\theta_{S E}=$ Local solar zenith angle; $\theta_{S Z}=90^{\circ} \theta_{S E}$.

\subsubsection{Land Surface Temperature (LST)}

As depicted by equation 3, LST can simply be defined as how hot the "surface" of the Earth would feel to the physical touch in a particular location [36] and depends on land use activities and land cover. This is estimated from the Top-of-Atmosphere (TOA) brightness temperatures derived from the infrared spectral channels satellites such as the Band 11 of Landsat-8 (Thermal Infrared Sensor) [37]. The justification for choosing these remote sensing techniques is based on evidence from previous studies that suggest that the difference between dumpsites and surrounding area LST can infer the degree/extent of biodegradation activities in the dumpsite, which causes greenhouse gases release and increases the temperature around the dumpsite area [38, 39]. Land Surface Temperature (LST) is given by:

$$
L S T=\frac{K_{2}}{\ln \left(\frac{K_{1}}{L_{\lambda}}+1\right)}
$$

Where LST is the at-satellite brightness temperature (K), $L_{\lambda}$ is the TOA spectral radiance (Watts/ $\left(\mathrm{m}^{2} \times \mathrm{s} \times \operatorname{rad} \times \mu \mathrm{m}\right), K_{1}$ is the band-specific thermal conversion constant and $K_{2}$ is the Band-specific thermal conversion constant $[40,41]$. To convert to degree Celsius, 273.5 is subtracted from the result of equation (3).

\subsubsection{Soil Adjusted Vegetation Index (SAVI)}

SAVI is one of the commonly used method for vegetation health mapping from remotely sensed images [42], and is applied here to infer the systematic response of vegetation to soil and groundwater contamination from dumpsites leachate [35, 40]. SAVI is calculated using the ratio between the near infrared and red bands, and takes into account soil background "fudge factor". The SAVI is derived from atmospherically corrected Landsat- 8 bands using the equation:

$$
S A V I=\left[\frac{(N I R-R E D)}{(N I R+R E D+L)}\right] \times(1+L)
$$


where: $\quad$ RED $=$ Band 4 , NIR $=$ Band 5 images from Landsat 8, L indicated the soil fudge that varies from 0 to 1 (default $=0.5$ ) [42]. Low SAVI values close to 0 indicates unhealthy vegetation, while areas where high SAVI values close to 1 indicates dense healthy vegetation [35].

\subsection{Proxy and statistical analysis of dumpsite waste deposit and microbial activities}

The quantity of solid waste generated in urban centres is rising continuously, following the trend of population, immigration and urbanization [29, 43, 44]. Typically, waste collected from urban centres are collected, transported and disposed of in dumpsites [45], thereby heaping up vertically within a designated area. SRTM measures elevations within 30 metre gridded cells; the average elevation cell values within the dumpsite defined area are extracted using zonal statistics function of ArcMap spatial analyst [46]. The relationship between LST and SAVI and microbial outcomes such as bacteria and fungi counts derived from previous studies [25] also were analysed using simple linear regression model.

\section{RESULTS AND DISCUSSION}

\subsection{Land Surface Temperature, Soil Adjusted Vegetation Index and Environmental effect}

Landsat 8 extracted Land Surface Temperature (LST) and Soil Adjusted Vegetation Index (SAVI) are applied to access the environmental impact of dumpsites. LST (Figure 5) depicts surrounding temperature of dumpsites and its environs, while SAVI (Figure 6) portrays environmental response to soil and ground water contamination caused by dumpsite leachate. Open burning of waste widely practised at Benin city dumpsites [12] and dumpsite gases that emanate from waste decomposition [35] are identified as the two possible factors that contribute to dumpsite temperature increase. Polluted leachate infiltration is potentially directly responsible for soil and groundwater contamination, consequently resulting in vegetation stress detected by the SAVI [38, 47]. The visual assessment shows that the dark red regions in Figure 5 indicate high LST and light green low LST, while the red regions in Figure 6 show high SAVI and blue depict low SAVI.

From Figure 5 and 6, Benin city built-up areas (the star-like feature in the full extent image) depicts the high urbanization density of Benin city, showed by high levels of LST and low SAVI. The uncertainty in urban LST caused by the varying reflectance and emissivity of man-made features [48, 49], makes it somewhat difficult to discriminate between urban and dumpsite temperatures. Hence, close-up presentations of the four (4) dumpsites (Oluku, Ugbowo, Ikhueniro, and Moat Owoseni Junction) are further displayed at the top right-hand corner of Figure 5 and 6 to display clearer details on how dumpsite differ from and possibly affect the surrounding environment.

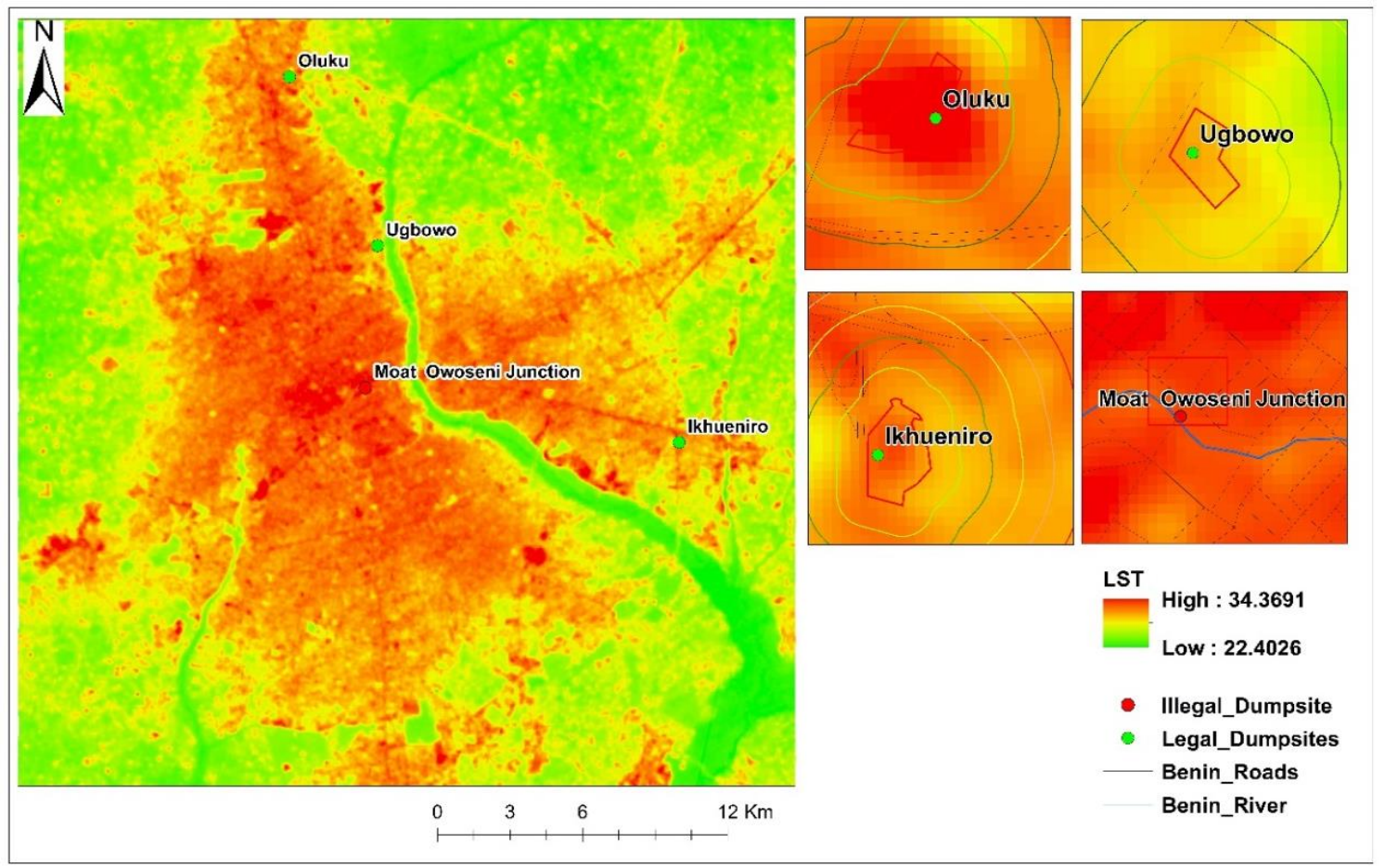

Figure 5: Land Surface Temperature (LST) Benin city 


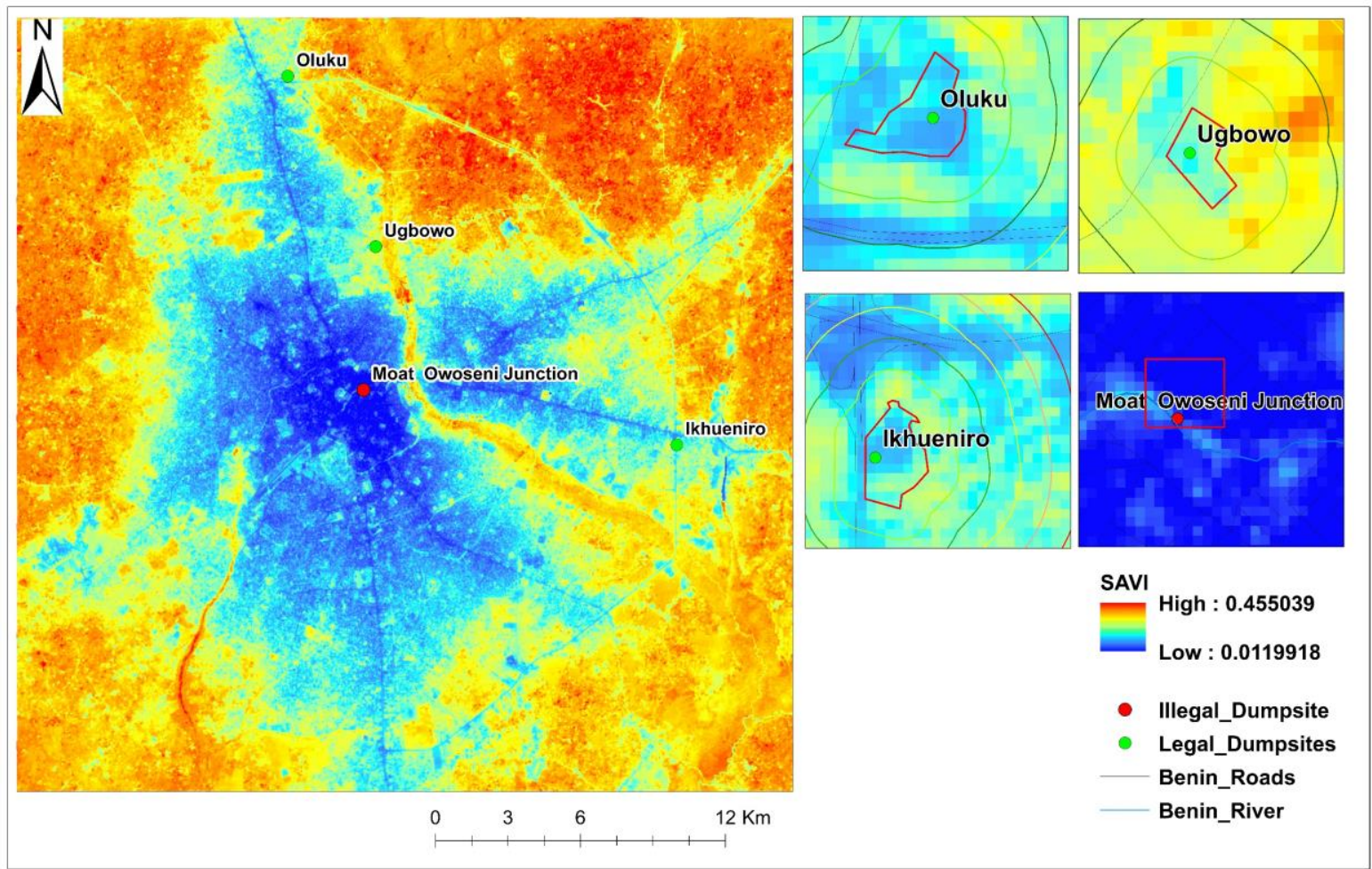

Figure 6: Soil Adjusted Vegetation Index (SAVI) Benin city

Dumpsites typical emit high levels of greenhouse gases to its surrounding environs [40], evident in Figure 5 (close-up) display. However, when dumpsites are located near roads (e.g. Owoseni Junction), road traffic emissions and urban land use activities corrupts the results $[50,51]$. Close-up display dumpsite SAVI values (Figure 6) that infer vegetation health show similar patterns as the LST but increases outwards from dumpsite. Unlike the barely visible impact urban land use on the LST displayed at the Owoseni Junction Moat, SAVI variability along the Moat is detectable, portraying possible contamination effect of waste disposal into the Moat. This finding is consistent with the results from Akujieze and Irabor [14], where significant levels of acidity, iron, lead, cadmium and aluminium contamination were detected in soil and groundwater within the Moat of Benin city. The decreasing trend of SAVI outwards from dumpsite is also similar to heavy metal decline away from Ugbowo and Evbuotubu sites previously presented in Aderoju et al., [24].

\subsection{Statistical comparison of ground monitored and satellite derivatives}

LST and SAVI values from three of the dumpsites in this study (Oluku, Ugbowo, and Ikhueniro) and bacterial and fungal count colony-forming unit (cfu) from a previous study, Egharevba et al., [25] were evaluated. Furthermore, the LST and SAVI for all sites were compared against the city average (Figure 8 and Table $3)$, to grasp the potential environmental impact around dumpsite locations and its variation from the city. Table 3 also presents the average dumpsite height derived from SRTM, applied as a proxy measure for the quantity of waste at each dumpsite. LST was found to be positively related to the dumpsite height, which corresponds with Chander et al., [52]'s disclosure of landfill gas emission sensitivity to the amount and composition of waste disposed.

Landfill gases such as methane $\left(\mathrm{CH}_{4}\right)$ usually emanate from microbial (bacterial and fungal) activities that facilitate waste decomposition at dumpsites [43, 53]. Egharevba et al., [25] documented bacterial and fungal counts at five dumpsites including Ikhueniro, Ugbowo and Oluku, where this study focused on. The bacterial and fungal counts correlated strongly with the LST and SAVI values at each of the dumpsites (Figure 8), R²: LST vs Bacteria Count $=0.982$, LST vs Fungi Count $=$ 0.951; SAVI vs Bacteria Count $=0.745$, SAVI vs Fungi Count $=0.664$. With 45 percent of waste generated in Benin city classified as bio-degradable [18], an increase in waste quantity is expected to result in high decomposition, gas emissions and contamination.

\section{CONCLUSION}

Urbanization and population growth within the local governments that constitute Benin city have resulted in increased consumption, production and consequently 
waste generation. Also, the growth in population and poorly planned urban sprawl within the confined land area has caused the settlement of persons close to open solid waste disposal sites, thus exposing themselves to possible pollution and contamination.

This study builds on the recently released status (legal and illegal) of dumpsites in Benin city, published on the Edo state open data portal. These Geocoded dumpsite data points were combined with satellite data (Landsat-8 and SRTM) and in-situ data from previous microbial studies to ascertain the impact of these dumpsites on the environment.

Our finding reveals that satellite derivatives such as Land Surface Temperature, Soil Adjusted Vegetation Indices and average dumpsite elevation were derived from SRTM DEM can be applied to assess the impact of dumpsites on the environment, as well as quantify the quantity of waste. LAT derivative capture changes in the air temperature around the dumpsite that emanate from biodegradation and possibly anthropogenic activities such as waste burning. SAVI indirectly detects vegetation response to soil and groundwater contamination caused by leachate infiltration, while the average elevation of the designated dumpsite infers the quantity of waste, as well as probable decomposition activities due to large organic waste volume. Furthermore, the RS approach applied in this study was consistent and correlated strongly with previous biophysical studies that assessed bacterial count, fungi count and toxicity, thereby providing strong evidence to support the applicability of remote sensing for dumpsite impact assessment. The integration of remote sensing's temporal component, which was not considered in this study, will further enhance longterm continuous dumpsite monitoring and management at reduced cost, effort and time.
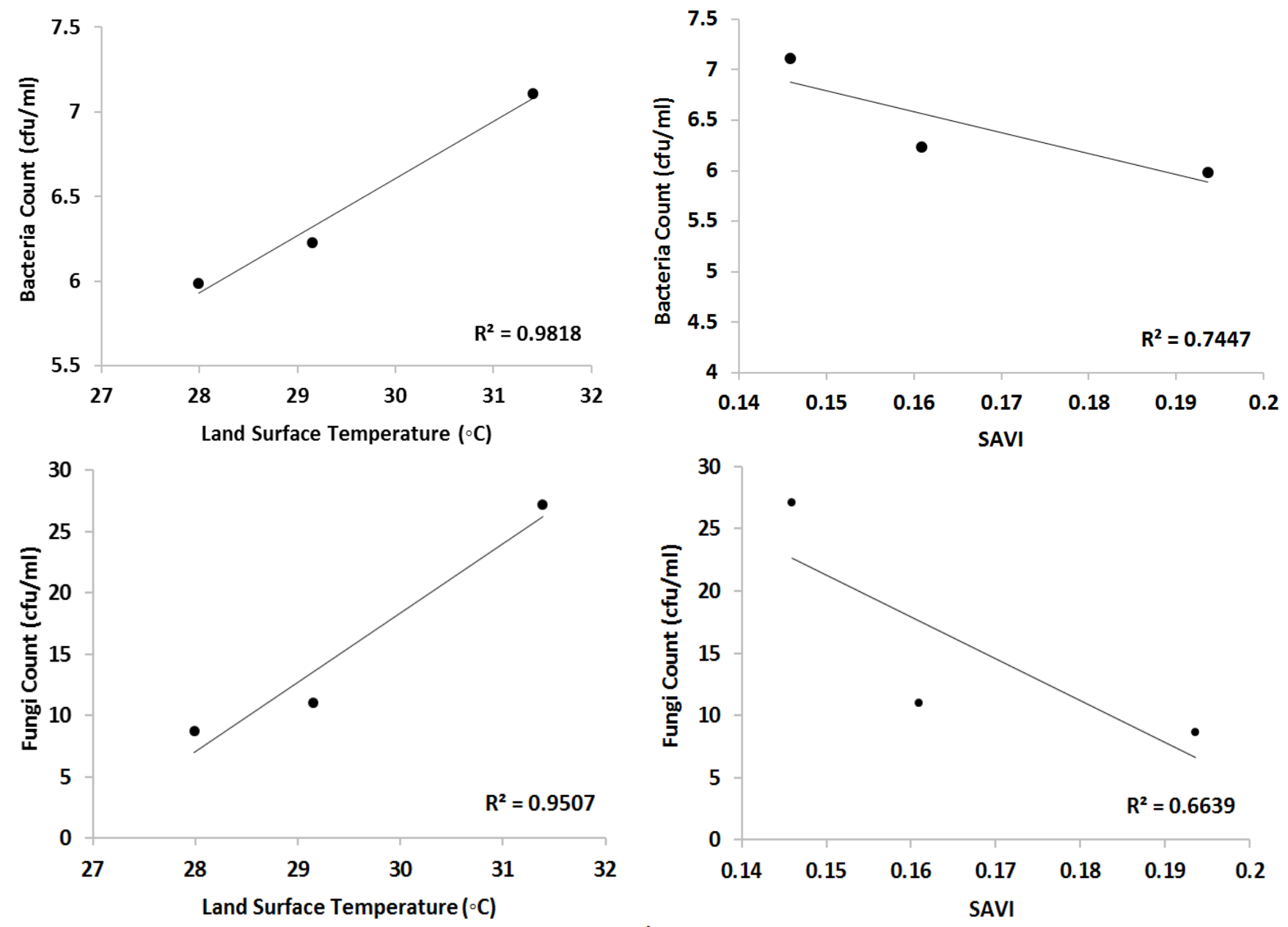

Figure 8: Relationship between Biological observations and Remote Sensing derivatives 
Table 3: Dumpsite parameters comparison

\begin{tabular}{lccccc}
\hline Site & Ikhueniro & Ugbowo & Oluku & Owoseni Junction & Benin City Min (Mean) Max \\
\hline LST & 29.146 & 27.991 & 31.393 & 29.919 & $22.403(26.663) 34.369$ \\
SAVI & 0.161 & 0.194 & 0.146 & 0.071 & $0.0119(0.236) 0.455$ \\
Area Height $(\mathrm{m})$ & 82.000 & 69.000 & 105.250 & 94.000 & - \\
\hline
\end{tabular}

Physio-chemical quality assessment - 12 inches (cfu/ml) [25]

$\begin{array}{llll}\text { Bacteria count } & 6.2300 & 5.9900 & 7.1100\end{array}$

$\begin{array}{llll}\text { Fungal count } & 11.0000 & 8.6700 & 27.1100\end{array}$

\section{ACKNOWLEDGEMENT}

The authors acknowledge Information Communication Technology Agency (ICTA), Edo State, Nigeria for providing the dumpsite coordinates and designation, as well as the population and land area data through the Edo Open Data platform used in this study.

\section{REFERENCES}

[1] S. A. Ahmed and M. Ali, "Partnerships for solid waste management in developing countries: linking theories to realities," Habitat International, vol. 28, no. 3, pp. 467-479, 2004.

[2] R. K. Annepu, "Sustainable solid waste management in India," Columbia University, New York, 2012.

[3] R. K. Henry, Z. Yongsheng, and D. Jun, "Municipal solid waste management challenges in developing countries - Kenyan case study," Waste Management, vol. 26, no. 1, pp. 92-100, 2006.

[4] L. A. Guerrero, G. Maas, and W. Hogland, "Solid waste management challenges for cities in developing countries," Waste Management, vol. 33, no. 1, pp. 220-232, 2013.

[5] M. Sharholy, K. Ahmad, G. Mahmood, and R. Trivedi, "Municipal solid waste management in Indian cities-A review," Waste management, vol. 28, no. 2, pp. 459-467, 2008.

[6] L. A. Manaf, M. A. A. Samah, and N. I. M. Zukki, "Municipal solid waste management in Malaysia: Practices and challenges," Waste management, vol. 29, no. 11, pp. 2902-2906, 2009.

[7] World Bank, "Planning, Connecting and Financing Cities -Now," ed. Washington DC: The World Bank, 2013.

[8] United Nations Department of Economic and Social Affairs Population Division, "World Urbanisation Prospects," New York: UNPD 2012.

[9] O. O. Magnus and J. O. Eseigbe, "Categorization of Urban Centres in Edo State, Nigeria," IOSR Journal of Business and Management (IOSRJBM), vol. 3, no. 6, pp. 19 - 25, 2012.
[10] P. A. O. Odjugo, G. O. Enaruvbe, and H. O. Isibor, "Geospatial approach to spatio-temporal pattern of urban growth in Benin City, Nigeria," African Journal of Environmental Science and Technology, vol. 9, no. 3, pp. 166-175, 2015.

[11] V. I. Ogu, "Housing and environmental services in Benin City, Nigeria," University of Cambridge, 1996.

[12] D. Igbinomwanhia and B. Ideho, "A Study of the Constraint to Formulation and Implementation of Waste Management Policies in Benin Metropolis, Nigeria," Journal of Applied Sciences and Environmental Management, vol. 18, no. 2, pp. 197-202, 2014.

[13] C. Abejegah et al., "Market Sanitation: A Case Study of Oregbeni Market Benin-City Edo State, Nigeria," International Journal of Basic, Applied and Innovative Research, vol. 2, no. 2, pp. 25-31, 2013.

[14] C. N. Akujieze and E. E. Irabor, "Assessment of environmental degradation of soil and groundwater: A case study of waste disposal in Benin West Moat-Ekenwan gully Benin City, Edo State, Nigeria," African Journal of Environmental Science and Technology, vol. 8, no. 6, pp. 381-390, 2014.

[15] D. Idiata, N. Agbale, and K. Iguisi, "Menace of Sachet Water Waste in Benin City, Nigeria," 2013.

[16] Environmental Law Research Institute (ELRI), "Compilation of Institutions \& Waste Management Regulations in Nigeria," 2011.

[17] M. O. Asikhia and D. Olaye, "SOLID WASTE MANAGEMENT IN BENIN CITY: AN APPRAISAL," The Nigerian Journal of Research and Production Volume, vol. 18, no. 2, 2011.

[18] P. Oseghale, "Waste management handling in Benin City," 2011.

[19] M. A. Hannan, M. Abdulla Al Mamun, A. Hussain, H. Basri, and R. A. Begum, "A review on technologies and their usage in solid waste monitoring and management systems: Issues and challenges," Waste Management, vol. 43, pp. 509-523, 2015. 
[20] F. Emmanuel, A. Musa, and Z. Nanpon, "Site suitability analysis and route optimization for solid waste disposal in Yola Town, Adamawa State Nigeria," South African Journal of Geomatics, vol. 6, no. 1, pp. 130-141, 2017.

[21] H. Achi, C. Adeofun, G. Ufoegbune, A. Gbadebo, and J. Oyedepo, "Disposal sites and transport route selection using geographic information system and remote sensing in Abeokuta, Nigeria," Global Journal of Human-Social Science Research, vol. 12, no. 12-B, 2012.

[22] A. I. Naibbi and U. M. Umar, "An Appraisal of Spatial Distribution of Solid Waste Disposal Sites in Kano Metropolis, Nigeria," Journal of Geoscience and Environment Protection, vol. 5, no. 11, p. 24, 2017.

[23] 0. M. Aderoju, A. G. Dias, and R. Guimarães, "Geospatial Technology as a Tool in Municipal Solid Waste Management and Monitoring in Nigeria," Journal of Solid Waste Technology \& Management, vol. 42, no. 1, 2016.

[24] E. Ukpebor, P. Oviasogie, and C. Unuigbe, "The distribution of $\mathrm{Mn}, \mathrm{Zn}, \mathrm{Cu}, \mathrm{Cr}, \mathrm{Ni}$, and $\mathrm{Pb}$ Around Two Major Refuse Dumpsites in Benin City, Nigeria," Pakistan Journal of Scientific and Industrial Research, vol. 46, no. 6, pp. 418-423, 2003.

[25] A. Egharevba, O. Amengialue, O. Edobor, and M. Omoigberale, "Microbiological and physicochemical quality assessment of solid waste dumpsites in Benin City, Nigeria," International Journal of Agriculture and Biosciences, vol. 2, no. 6, pp. 344-348, 2013.

[26] Information Communication Technology Agency, "Edo State Open Data/Environment," ed, 2016.

[27] N. P. Commission, "Population and housing census of the Federal Republic of Nigeria," Priority tables, vol. 1, 2006.

[28] E. F. Ogunbodede and T. F. Balogun, "An integrated remote sensing and GIS approach in monitoring urban expansion in Benin City, Nigeria," International Journal of Scientific \& Engineering Research, vol. 4, no. 5, pp. 734-758, 2013.

[29] N. Momodu, K. Dimuna, and J. Dimuna, "Mitigating the impact of solid wastes in urban centres in Nigeria," Journal of human ecology, vol. 34, no. 2, pp. 125-133, 2011.

[30] J. R. Irons, J. L. Dwyer, and J. A. Barsi, "The next Landsat satellite: The Landsat Data Continuity Mission," Remote Sensing of Environment, vol. 122, pp. 11-21, 2012.

[31] T. G. Farr and M. Kobrick, "Shuttle radar topography mission produces a wealth of data,"
Eos, Transactions American Geophysical Union, vol. 81, no. 48, pp. 583-585, 2000.

[32] R. J. Hijmans et al., "DIVA-GIS: Country level data," 2004.

[33] R. Richter, "A spatially adaptive fast atmospheric correction algorithm," International Journal of Remote Sensing, vol. 17, no. 6, pp. 1201-1214, 1996.

[34] G. Chander, B. L. Markham, and J. A. Barsi, "Revised Landsat- 5 Thematic Mapper Radiometric Calibration," Geoscience and Remote Sensing Letters, IEEE, vol. 4, no. 3, pp. 490-494, 2007.

[35] A. Shaker and W. Y. Yan, "Trail road landfill site monitoring using multioral landsat satellte data," vol. 38, ed, 2010.

[36] Y. Zhang, I. A. Odeh, and E. Ramadan, "Assessment of land surface temperature in relation to landscape metrics and fractional vegetation cover in an urban/peri-urban region using Landsat data," International Journal of Remote Sensing, vol. 34, no. 1, pp. 168-189, 2013.

[37] M. Sahana, R. Ahmed, and H. Sajjad, "Analyzing land surface temperature distribution in response to land use/land cover change using split window algorithm and spectral radiance model in Sundarban Biosphere Reserve, India," Modeling Earth Systems and Environment, vol. 2, no. 2, pp. 1-11, 2016.

[38] K. Yang, X. Zhou, W. Yan, D. Hang, and P. Steinmann, "Landfills in Jiangsu province, China, and potential threats for public health: Leachate appraisal and spatial analysis using geographic information system and remote sensing," Waste Management, vol. 28, no. 12, pp. 2750-2757, 2008.

[39] A. Y. Kwarteng and A. Al-Enezi, "Assessment of Kuwait's Al- Qurain Landfill Using Remotely Sensed Data," Journal of Environmental Science and Health, Part A, vol. 39, no. 2, pp. 351-364, 2004.

[40] B. Ahmed, M. D. Kamruzzaman, X. Zhu, M. D. Shahinoor Rahman, and K. Choi, "Simulating land cover changes and their impacts on land surface temperature in dhaka, bangladesh," Remote Sensing, vol. 5, no. 11, pp. 5969-5998, 2013.

[41] Y.-h. Chen, J. Wang, and X.-b. Li, "A study on urban thermal field in summer based on satellite remote sensing," Remote Sensing for Land and Resources, vol. 4, no. 1, 2002.

[42] A. R. Huete, "A soil- adjusted vegetation index (SAVI)," Remote Sensing of Environment, vol. 25, no. 3, pp. 295-309, 1988.

[43] O. Ogunmodede, E. Adewole, O. Ajayi, and A. Onifade, "Environmental Assessment of Solid 
Waste Management In Nigeria: A Case Study of Ikere Ekiti, Ekiti State," Journal of Physical and Chemical Sciences, vol. 1, no. 1, pp. 1-8, 2014.

[44] R. Pai, L. L. Rodrigues, A. O. Mathew, and S. Hebbar, "Impact of urbanization on municipal solid waste management: a system dynamics approach," Int J Renew Energy Environ Eng, vol. 2, pp. 2348-0157, 2014.

[45] B. Nas, T. Cay, F. Iscan, and A. Berktay, "Selection of MSW landfill site for Konya, Turkey using GIS and multi- criteria evaluation," Environ Monit Assess, vol. 160, no. 1, pp. 491-500, 2010.

[46] ESRI, "Advanced GIS Spatial Analysis Using Raster and Vector Data," An ESRI White Paper, ESRI (Environmental Systems Research Institute), Redlands, USA, 2001.

[47] G. Gałko, "The influence of infiltration of leachate from landfills on the changes of chemical parameters of the soil," Journal of Ecological Engineering, vol. 16, no. 4, pp. 198-205, 2015.

[48] J. Yang, M. S. Wong, M. Menenti, and J. Nichol, "Study of the geometry effect on land surface temperature retrieval in urban environment," ISPRS Journal of Photogrammetry and Remote Sensing, vol. 109, pp. 77-87, 2015.
[49] F. Chen, S. Yang, K. Yin, and P. Chan, "Challenges to quantitative applications of Landsat observations for the urban thermal environment," Journal of Environmental Sciences, vol. 59, pp. 80-88, 2017.

[50] N. Jamaludin, N. I. Mohammed, M. F. Khamidi, and S. N. A. Wahab, "Thermal Comfort of Residential Building in Malaysia at Different Micro- climates," Procedia - Social and Behavioral Sciences, vol. 170, pp. 613-623, 2015.

[51] P. Rajagopalan, L. K. Chuan, and E. Jamei, "Urban heat island and wind flow characteristics of a tropical city," Solar Energy, 2014.

[52] S. Chander Kumar, K. Anand, and R. Soumendu Shekhar, "Estimating Potential Methane Emission from Municipal Solid Waste and a Site Suitability Analysis of Existing Landfills in Delhi, India," Technologies (Basel), vol. 5, no. 4, p. 62, 2017.

[53] H. I. Inyang and H. Hilger, "Molecular and biological techniques used in landfill investigations: A mini-review," Biotechnology and Molecular Biology Reviews, vol. 8, no. 2, pp. 35-42, 2013.

[54] O. H. Uchendu, "Household Waste Disposal Laws in the Federal Republic of Nigeria," School of Public Health, Georgia State University College of Law, 2016. 